\title{
Nicotine Modulates Growth Factors and MicroRNA to Promote Inflammatory and Fibrotic Processes ${ }^{\text {[ }}$
}

\author{
Afshin Ebrahimpour, Samana Shrestha, Mark D. Bonnen, N. Tony Eissa, Ganesh Raghu, \\ and Yohannes T. Ghebre \\ Departments of Radiation Oncology (A.E., S.S., M.D.B., Y.T.G.) and Medicine, Section on Pulmonary and Critical Care Medicine \\ (N.T.E., Y.T.G.), Baylor College of Medicine, Houston, Texas; and Division of Pulmonary and Critical Care Medicine, Center for \\ Interstitial Lung Disease, University of Washington, Seattle, Washington (G.R.)
}

Received August 5, 2018; accepted November 1, 2018

\begin{abstract}
Idiopathic pulmonary fibrosis (IPF) is a fatal disease that destroys the structure and function of the lungs. Risk factors include advanced age and genetic predisposition. However, tobacco use is the chief modifiable risk factor. The prevalence of tobacco use in IPF reaches up to $80 \%$. Although tobacco smoke contains over 5000 chemicals, nicotine is a major component. Nicotine is a bioactive molecule that acts upon nicotinic acetylcholine receptors expressed on neuronal and non-neuronal cells including endothelial cells. Accordingly, it has a pleiotropic effect on cell proliferation and angiogenesis. The angiogenic effect is partly mediated by stimulation of growth factors including fibroblast, platelet-derived, and vascular endothelial growth factors. Nintedanib, a Food and Drug Administration-approved drug for IPF, works by inhibiting receptors for these growth factors, suggesting a pathobiologic role of the
\end{abstract}

growth factors in IPF and a potential mechanism by which tobacco use may exacerbate the disease process; additionally, nicotine downregulates anti-inflammatory microRNAs (miRs) in lung cells. Here, we profiled the expression of miRs in lung tissues explanted from a lung injury model and examined the effect of nicotine on one of the identified miRs (miR-24) and its downstream targets. Our data show that miR-24 is downregulated during lung injury and is suppressed by nicotine. We also found that nicotine upregulates the expression of inflammatory cytokines targeted by miR-24. Finally, nicotine stimulated growth factors, fibroblast proliferation, collagen release, and expression of myofibroblast markers. Taken together, nicotine, alone or as a component of tobacco smoke, may accelerate the disease process in IPF through stimulation of growth factors and downregulation of anti-inflammatory miRs.

\section{Introduction}

Idiopathic pulmonary fibrosis (IPF) is a rare but fatal form of lung fibrosis. It has histologic features of usual interstitial pneumonia with impaired vital capacity and gas exchange, but without evidence for an alternative diagnosis (Raghu et al., 2015). Some of the classic features of IPF are early alveolar inflammation (Kolb et al., 2001; dos Santos et al., 2012) followed by progressive accumulation of collagen, leading to lung scarring, dyspnea, and death within 3-5 years of diagnosis. IPF has an incidence of 93.7 cases and prevalence of 494.5 cases per 100,000 (Raghu et al., 2014). Medical therapies for IPF are suboptimal. Recently, the Food and Drug Administration has approved two drugs, pirfenidone and nintedanib. However, these drugs only slow the disease progression in patients with mild-to-moderate disease (Raghu

This work was in part supported by the National Institutes of Health National Heart, Lung, and Blood Institute [Grants K01HL118683 and R01HL137703]; the American Heart Association [Grant 17GRNT33460159]; the Houston Methodist Research Institute; the Caroline Weiss Law Fund for Research in Molecular Medicine at Baylor College of Medicine (BCM); and intramural funding from the Department of Radiation Oncology at BCM.

https://doi.org/10.1124/jpet.118.252650.

S This article has supplemental material available at jpet.aspetjournals.org. and Thickett, 2013; Richeldi et al., 2014). Therefore, there is a compelling need to develop more efficacious therapies. This possibility might be facilitated through complete characterization of the major risk factors that are already linked to IPF.

To date, over 140 agents have been associated with the development and/or progression of pulmonary fibrosis. Many of these agents are often encountered through occupationa1/environmental exposure and include radiation, metal dusts, and asbestos. In addition, genetic polymorphisms and exposure to cigarette smoke are among the risk factors for IPF. Intriguingly, current or former smokers represent a large proportion of IPF patients, ranging from $41 \%$ to $83 \%$ (Ryu et al., 2001), and have a worse prognosis, including accelerated loss of lung function. Recent epigenetic studies indicate that cigarette smoke is the most strongly associated environmental risk factor for IPF (Yang and Schwartz, 2015). This strong association of tobacco use with IPF suggests that smoking is a chief risk factor in the development and/or progression of the disease (Samara et al., 2011; Margaritopoulos et al., 2015, 2016). In accordance with this consideration, preclinical studies have demonstrated that cigarette smoke causes airway epithelial cell damage (Kuipers et al., 2011; Nyunoya et al., 2014; Solleti et al., 2015) and global epigenetic changes, including DNA

ABBREVIATIONS: ACh, acetylcholine; BrdU, 5-bromo-2-deoxyuridine; ELISA, enzyme-linked immunosorbent assay; FGF, fibroblast growth factor; IPF, idiopathic pulmonary fibrosis; miR, microRNA; nAChR, nicotinic acetylcholine receptor; PBS, phosphate-buffered saline; PDGF, platelet-derived growth factor; TGF, transforming growth factor; VEGF, vascular endothelial growth factor. 
methylation and chromatin remodeling, which negatively impact genes involved in physiologic lung repair and regeneration (Hagood, 2014; Bellaye and Kolb, 2015; Yang and Schwartz, 2015). However, the precise mechanism by which tobacco use contributes to IPF pathobiology and the effect of nicotine in the disease process are largely unknown. Tobacco smoke contains over 5000 mixtures of toxic and carcinogenic chemicals including nitrosamines, heavy metals, and nicotine (Talhout et al., 2011). Of these components, nicotine is a major ingredient and is responsible for the craving and addictive action. Several studies have reported that nicotine, at clinically relevant concentrations achievable in the plasma of moderate smokers (i.e., 10-100 nM) (Hill et al., 1983; Matta et al., 2007), is biologically active (Duan et al., 2015; NouriShirazi et al., 2015; Schweitzer et al., 2015).

Previously, we (Cooke and Ghebremariam, 2008) and others (Kummer et al., 2008; Maouche et al., 2009; Kummer and Krasteva-Christ, 2014) have reported that nonexcitable cells (e.g., endothelial and epithelial cells) possess components of the nicotinic acetylcholine ( $\mathrm{ACh}$ ) machinery including nicotinic acetylcholine receptors ( $\mathrm{nAChRs),} \mathrm{acetyltransferase,}$ acetylcholinesterase, and choline transporters (Fig. 1). This machinery is responsible for the production, storage, secretion, and breakdown of $\mathrm{ACh}$; an endogenous hormone that activates $\mathrm{nAChRs}$ to exert autocrine and paracrine effects. The nAChRs are composed of five subunits with 16 different isoforms arranged as $\alpha / \beta$ heteromeric or $\alpha$ homomeric units $(\alpha 1-\alpha 7$, $\alpha 9, \alpha 10, \beta 1-\beta 4, \delta, \gamma$, and $\varepsilon ; \alpha 8$ is avian restricted). Studies have shown that lung fibroblasts and epithelial cells express functional $\mathrm{nAChRs}$ that are responsive to endogenous agonists such as $\mathrm{ACh}$ and to exogenous stimulation by nicotine (Maus et al., 1998; Carlisle et al., 2004). Notably, tobacco exposure does not appear to alter the composition and/or distribution of nAChRs in lung cells (Carlisle et al., 2004). Of the nAChRs expressed in airway cells, the $\alpha 7 \mathrm{nAChR}$ is relatively well characterized, including its involvement in ion permeability, proliferation, epithelium differentiation, fetal lung development, and function (Sekhon et al., 1999, 2001; Nastrucci and Russo, 2012). It is also the $\alpha 7 \mathrm{nAChR}$ that is preferentially activated by nicotine (Cooke and Ghebremariam, 2008). As a result, nicotine exerts its detrimental effect on the vascular system including promoting inflammation, collagen turnover, and angiogenesis (Carty et al., 1996; Cucina et al., 2000; Jensen et al., 2012). The angiogenic effect of nicotine is in part mediated by excessive stimulation of growth factors including fibroblast growth factor (FGF), platelet-derived growth factor (PDGF), and vascular endothelial growth factor (VEGF) (Carty et al., 1996; Cucina et al., 2000; Conklin et al., 2002; Ornitz and Itoh, 2015), as well as their receptors (Grozio et al., 2007). Intriguingly, the Food and Drug Administration-approved antifibrotic drug nintedanib (BIBF 1120) works by inhibiting the receptors for FGF, PDGF, and VEGF, suggesting a pathobiological role of these mitogenic growth factors as well as a potential mechanism by which tobacco use may potentiate the disease process in IPF.

Recently, we discovered that nicotine downregulates antiinflammatory microRNAs (miRs), including miR-24 in primary human lung epithelial and endothelial cells. Many of the predicted targets of miR-24 are proinflammatory cytokines and FGF; stimuli that are known to play a pathophysiological role in IPF. Being highly conserved noncoding RNA molecules that are involved in post-transcriptional repression of genes (Lee et al., 1993), miRs have recently emerged as key modulators of lung disease. To date, several miRs have been demonstrated to play significant roles in the disease process in IPF (Pandit et al., 2010, 2011; Milosevic et al., 2012; Yang et al., 2012, 2013; Lino Cardenas et al., 2013; Montgomery et al., 2014). For example, microarray analysis of normal and IPF lung tissue samples revealed that about $10 \%$ of miRs are differentially expressed in IPF lungs (Milosevic et al., 2012). Many of these miRs are predicted to be directly governed by transforming growth factor (TGF) $\beta$ and are involved in fibrogenesis and aberrant lung remodeling (Pandit and Milosevic, 2015). Recently, the important role of miRs in IPF disease pathogenesis has compelled the National Institutes of Health to support the development of an "IPF map project"; a web-based resource for genomic and transcriptomic profiling of mRNA and miR transcripts derived from IPF lungs.

Little is known about the genomic and epigenetic effects of tobacco smoke or its components in the context of IPF. There are only a limited number of studies that looked at the differential effect of nicotine on miRs. For example, in a canine model of atrial fibrosis Shan et al. (2009) demonstrated that nicotine downregulated two antifibrotic miRs (miR-133 and miR-590), resulting in stimulation of atrial fibroblast proliferation, TGF $\beta 1$ expression, and collagen accumulation.

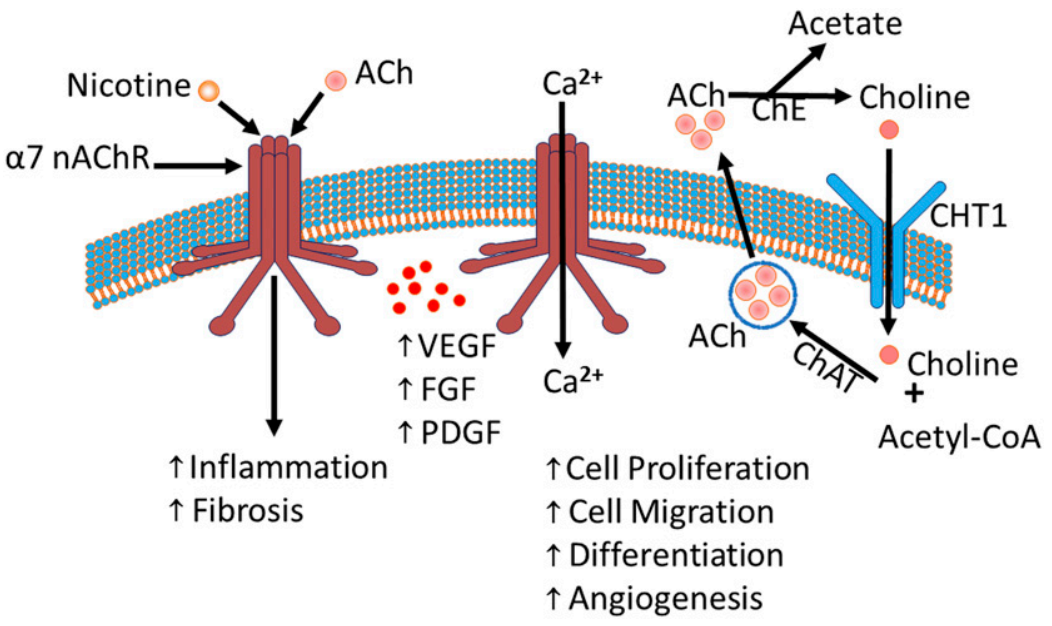

Fig. 1. The nicotinic acetylcholine machinery: ACh or nAChRs, including the homomeric $\alpha 7 \mathrm{nAChR}$ promote growth factors (VEGF, FGF, and PDGF) and influence several physiologic processes including cell proliferation, migration, differentiation, and angiogenesis, as well as pathologic conditions, including inflammation and fibrosis. Permeability of the $\alpha 7 \mathrm{nAChR}$ to cations (e.g., $\mathrm{Ca}^{2+}$ ) is shown. In addition, the degradation of ACh into choline, the internalization of choline and its recycling to form $\mathrm{ACh}$ molecules is shown. $\mathrm{Ca}^{2+}$, calcium; ChAT, choline acetyltransferase; $\mathrm{ChE}$, choline esterase; CHT1, choline transporter. 
The nicotine-induced fibrogenesis and downregulation of miRs in that study was mediated by $\alpha 7 \mathrm{nAChR}$ and was reversed by pretreatment with a selective $\alpha 7 \mathrm{nAChR}$ antagonist, $\alpha$-bungarotoxin (Shan et al., 2009). A recent study in Caenorhabditis elegans (C. elegans) demonstrated that nicotine altered the miR expression profile of $17 \%$ of the worm's total miR, accounting for nearly 3000 coregulated genes (Taki et al., 2014). Given that up to $80 \%$ of C. elegans genes, including nAChRs, are conserved in humans (Vella and Slack, 2005), this finding has important implications in tobacco-related disease research, including IPF.

In the present study, we examined the effect of nicotine at clinically relevant concentrations on growth factors known to stimulate tyrosine kinase receptors, as well as on antiinflammatory/antifibrotic miRs including miR-24 and its predicted downstream targets. In addition, we assessed the effect of nicotine on the proliferation of lung fibroblasts and accumulation of collagen.

\section{Materials and Methods}

Isolation of MicroRNAs from Bleomycin-Induced Lung Injury Model. Lung fibrosis was established in a rat model of acute lung injury by a single intratracheal instillation of bleomycin as we described previously (Ghebremariam et al., 2015). In brief, anesthetized male Fischer F344 rats were instilled with normal saline (sham) or bleomycin sulfate $(4 \mathrm{mg} / \mathrm{kg})$ intratracheally on study day 0 and were followed for 28 days to assess lung inflammation and fibrosis. In the present study, the right lung lobes harvested from the sham and bleomycin-injured animals that did not receive any active drug were used for the microRNA expression study described subsequently. Total RNA (including miRs) was isolated using TRIzol Reagent (Invitrogen, Carlsbad, CA), and the concentration and purity of the RNA samples were validated using a NanoDrop spectrophotometer. Mature miR in the isolated RNA samples was reverse transcribed into cDNA using the TaqMan MicroRNA Reverse Transcription Kit (Applied Biosystems, Foster City, CA). Finally, the cDNA was amplified using a quantitative real-time polymerase chain reaction technique to screen for the expression of miRs that have been linked to tissue inflammation and fibrosis, including miR-17, miR-20, miR-21, miR-24, miR-29, miR-30a, miR-34a, miR-133a, miR-155, miR-199a, miR-214, miR-224, miR-205, miR-335, miR-362, miR-338, miR-377, and miR-483; these miRs have been previously linked to inflammation and/or fibrosis in at least one tissue type.

Amplification of miR-24 in Nicotine-Treated Lung Epithelial Cells. Normal human lung epithelial cells (Lonza, Allendale, NJ) were grown in $75 \mathrm{~cm}^{2}$ tissue culture flasks at $37^{\circ} \mathrm{C} / 5 \% \mathrm{CO}_{2}$ in bronchial epithelial cell growth media supplemented with serum, growth factors, and antibiotics (Lonza) until about $70 \%$ confluency. Next, the cells were treated with nicotine (Sigma, St. Louis, MO) at concentrations achievable in the plasma of smokers $(\leq 500 \mathrm{nM})$ in the presence of vehicle [phosphate-buffered saline (PBS)] control for 24 hours. Subsequently, the cells were dissociated using Accutase solution (Sigma) treatment for 3 minutes at $37^{\circ} \mathrm{C}$. The cells were pelleted down by centrifugation at $600 \mathrm{~g}$ for 5 minutes and washed with PBS. Subsequently, total RNA (including mRNA and miR) was isolated and purified using miRNeasy Mini Kit (Qiagen, Germantown, MD) following the purveyor's guide. Finally, miR-24, identified in the aforementioned study, was amplified by quantitative reverse transcription polymerase chain reaction. The mRNA samples were used to run the TaqMan OpenArray Human Inflammation Panel (Life Technologies, Waltham, MA) in 3072-well microfluidic plates coated with TaqMan primers and probes.

Proliferation of Nicotine-Treated Lung Fibroblasts. Normal human lung fibroblasts (Lonza) were cultured in a 96 -well plate in FGM-2 media (Lonza) containing $2 \%$ fetal bovine serum at $37^{\circ} \mathrm{C} / 5 \%$ $\mathrm{CO}_{2}$. The cells $\left(3 \times 10^{3}\right)$ were incubated overnight prior to synchronization by a pulse of serum starvation and low serum $(0.1 \%)$ for
24 hours. The next day, the cells were stimulated with media containing $10 \%$ serum in the presence of nicotine (1-100 nM final concentration) or vehicle (PBS) for another 24 hours. Subsequently, the cells were incubated with 5-bromo-2-deoxyuridine [(BrdU); 1:500 dilution] for 22 hours to assess the effect of nicotine on proliferation. The incorporation of BrdU into the DNA of proliferating cells was detected using anti-BrdU antibody followed by absorbance measurement at $450 \mathrm{~nm}$ as per the protocol provided in the BrdU Cell Proliferation Assay Kit (Millipore, Burlington, MA).

Gene Expression of Inflammatory and Fibrotic Cytokines Following Treatment with Nicotine or miR-24 Inhibitor. Two micrograms of RNA isolated from the nicotine or miR-24 inhibitor-treated (assay ID: MH10737; has-miR-24-3p; mirVana miRNA inhibitor; Life Technologies) human lung epithelial cells or fibroblasts was reverse transcribed per cell type as described previously. The resulting cDNA was used for gene expression studies to screen for the expression pattern of classic inflammatory cytokines. In addition, the nicotine-treated samples were used to evaluate the expression of additional human inflammation and fibrosis-related genes using the TaqMan OpenArray Human Inflammation Panel (Life Technologies) as described previously. Confirmatory quantitative reverse transcription polymerase chain reaction was performed using standard TaqMan gene expression assay subunit-specific "best coverage" primer/probe sets (Applied Biosystems).

Effect of Nicotine on Soluble Collagen Release. For this study, we seeded normal human lung fibroblasts at a density of $6 \times$ $10^{4}$ cells/well in six-well plates and cultured them overnight at $37^{\circ} \mathrm{C} / 5 \%$ $\mathrm{CO}_{2}$. The next day, the media were aspirated and the cells were rinsed with PBS prior to overnight synchronization as described previously. On day 3 , the cells were stimulated with fully supplemented Dulbecco's modified Eagle's media (Life Technologies) containing $10 \%$ fetal bovine serum in the absence or presence of recombinant TGF $\beta 1$ (at $10 \mathrm{ng} / \mathrm{ml}$; Peprotech (Rocky Hill, NJ)) and nicotine (100 nM), miR-24 inhibitor (30 nM), or vehicle for 24 hours. Subsequently, the acid-soluble collagen content in each well was determined in the conditioned media using Biocolor's Sircol Collagen Assay Kit (Accurate Chemical and Scientific Corp., Westbury, NY) following the recommended protocol. The amount of collagen in each well was estimated from a standard curve and the collagen content in each sample was normalized to the total cellular protein in the respective well. Data were expressed as microgram collagen per milligram of protein.

Effect of Nicotine on Growth Factors: VEGF, FGF, and PDGF. To measure the concentration of VEGF, FGF, and PDGF, primary human lung endothelial cells were seeded on $75 \mathrm{~cm}^{2}$ flasks and cultured until about $80 \%$ confluency in EBM2 media (Lonza). Subsequently, the cells were treated with nicotine (1-100 nM) or PBS control for 24 hours. Conditioned media were collected and centrifuged at $600 \mathrm{~g}$ for 5 minutes for enzyme-linked immunosorbent assay (ELISA). The conditioned media and cells were harvested and total protein was extracted for normalization and measurement of intracellular growth factor concentration. For the ELISA assays, the concentration of VEGF was quantified using the Human VEGF ELISA Kit (Life Technologies), the concentration of FGF was measured using the Human FGF Basic Assay Kit (Invitrogen), and the concentration of PDGF was measured using the Human PDGF-BB ELISA Kit (Thermo Scientific, Waltham, MA). In brief, $100 \mu \mathrm{l}$ standards, cell lysate, or conditioned media (diluted in standard diluent buffer) were added to microtiter wells and incubated for 2 hours at room temperature. The wells were washed prior to incubation with biotinylated antibody for another hour at room temperature. Subsequently, $100 \mu \mathrm{l}$ of streptavidin/horseradish peroxidase reagent was added to each well, except for the blanks, and incubated for 30 minutes. Finally, the wells were washed and incubated with $100 \mu \mathrm{l}$ of substrate for detection. Absorbencies were measured at $450 \mathrm{~nm}$ and the concentration of growth factor in the samples was calculated from the standard curve.

Immunofluorescence Staining of Lung Fibroblasts Exposed to Prolonged Nicotine Treatment. To assess whether nicotine increases the expression of myofibroblast markers, primary human 
lung fibroblasts (Lonza) were seeded in gelatin-coated coverslips immersed in six-well plates in the absence or presence of nicotine $(100 \mathrm{nM})$ for 5 days. Subsequently, the cells were fixed in PBS-diluted 4\% paraformaldehyde (ThermoFisher) for 15 minutes at room temperature and rinsed with PBS prior to permeabilization with $0.2 \%$ Triton-X (Sigma) for 10 minutes at room temperature. Background signal was blocked with $2 \%$ nonfat milk for 1 hour at room temperature and the cells were stained for $\alpha$ smooth muscle actin (1:400; Abcam, Cambridge, UK) and type I collagen (1:500; Abcam). Finally, the cells were rinsed three times in PBS containing $0.05 \%$ Tween 20 (Sigma) and stained with goat anti-rabbit (1:500; ThermoFisher) Alexa Fluor 594 secondary antibody. The nuclei were stained with 4',6-diamidino-2-phenylindole ( $10 \mathrm{mg} / \mathrm{ml}$; ThermoFisher) for $5 \mathrm{~min}$ utes and kept in PBS until mounting. Immunofluorescence images were captured using a camera integrated to a Leica DM IL LED fluorescence microscope (Leica Microsystems, Buffalo Grove, IL).

Statistical Analysis. GraphPad Prism software (GraphPad, La Jolla, CA) was used to perform statistical tests in the in vitro cell culture studies. Groups of two were compared using Student's $t$ test, and multiple groups were compared using one-way analysis of variance followed by correction using the Bonferroni post-test.

Study Approval. The animal study from which lung tissue was obtained was reviewed and approved by the Lovelace Respiratory Research Institute Vertebrate Animal Use Research Committee, (Albuquerque, NM) (approval FY14-084) as described in Ghebremariam et al. (2015).

\section{Results}

Differential Regulation of miR Expression in Experimental Fibrosis. Among the screened microRNAs, we have successfully confirmed that most of them are detectable in the sham and bleomycin-injured groups. Of these detected miRs, we found that miR-24, -199a, -214, -335, and -483 were significantly changed in the bleomycin-injured fibrotic lungs compared with the sham $(P<0.05)$ (Supplemental Fig. 1). Because of its novelty in lung injury, we pursued miR-24 for subsequent studies. In a follow-up study, the expression of miR-24 and the housekeeping gene U6 was amplified using the TaqMan MicroRNA Assay (Applied Biosystems). We confirmed that miR-24 was significantly downregulated in the bleomycin-injured lungs (Fig. 2), suggesting a novel role for this miR in lung remodeling.

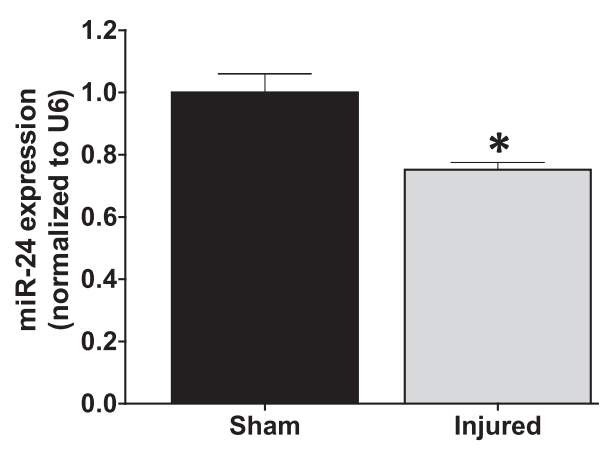

Fig. 2. miR-24 expression is reduced in lungs explanted from animal model of bleomycin-induced lung injury. Lung injury was induced in F344 Fischer rats through a single intratracheal administration of bleomycin at $4 \mathrm{mg} / \mathrm{kg}$ body weight. Animals were euthanized 28-days post-bleomycin injury and the right lung lobes were used for miR expression studies. Data are mean \pm S.E.M. from duplicate experiments $(n=3)$. The noncoding small nuclear RNA U6 was used as the loading control and to normalize the expression of miR-24 in the samples. ${ }^{*} P<0.05 \mathrm{vs}$. sham.
Nicotine Downregulates miR-24 Expression. Given the association of tobacco smoke and dysregulated lung function, we further tested the hypothesis that the major ingredient, nicotine, enhances inflammatory processes at least in part through inhibition of anti-inflammatory miRs. Given its anti-inflammatory role in a tobacco smoke-related disease (Maegdefessel et al., 2014) and association with lung injury in our model, we examined the effect of nicotine on miR-24 in epithelial cells; a cell type with a repertoire of the cholinergic acetylcholine machinery (Lam et al., 2016) and a prominent role in nicotine/tobacco smoke-related lung diseases (Heijink et al., 2012). Treatment of primary human lung epithelial cells at clinically relevant concentrations of nicotine (Hill et al., 1983) revealed dose-dependent reduction of miR-24 expression (Fig. 3). Notably, the dysregulation of miR-24 during the course of lung injury (Fig. 2) and its more pronounced suppression by nicotine (Fig. 3) suggest that cigarette smoke may accelerate the disease process in IPF at least in part due to excessive inhibition of miR-24 and subsequent loss of regulation on predicted miR-24 targets including proinflammatory cytokines. A recent preclinical study reported that miR-24 is involved in vascular inflammation through derepression of proinflammatory cytokines (Maegdefessel et al., 2014). One of the reported key targets of miR-24 is chitinase 3 -like 1; a cartilage glycoprotein that is shown to be upregulated in IPF (Zhou et al., 2014).

miR-24 Regulates Inflammatory Cytokines. The gene expression study of representative miR-24 target genes after treatment of lung epithelial cells with a miR-24 inhibitor revealed upregulation of these proinflammatory molecules (Fig. 4), indicating that miR-24 indeed targets these cytokines in lung cells. Upregulation of classic inflammatory molecules such as soluble TNF- $\alpha$, IL $1 \beta$, and $\mathrm{NF}_{\kappa} \mathrm{B}$ have been reported in the bleomycin model of lung injury and IPF patients (Serrano-Mollar et al., 2003; Oikonomou et al., 2006; Wilson et al., 2010). Studies have also shown sustained expression of TGF $\beta$ in an animal model that overexpresses IL1 $\beta$ (Kolb et al., 2001).

Nicotine Coregulates Inflammatory Cytokines that Are Regulated by miR-24. Pretreatment of lung epithelial cells with nicotine also mirrored derepression of the

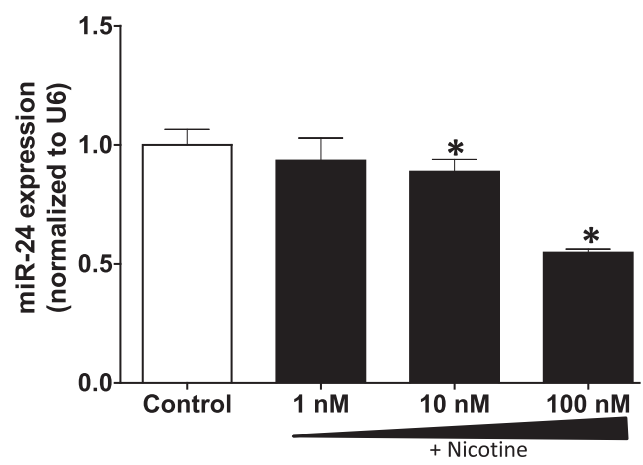

Fig. 3. Nicotine dose dependently downregulates the expression of miR24 in lung epithelial cells. Primary human lung epithelial cells were treated with nicotine $(1-100 \mathrm{nM})$ or control (PBS) for 24 hours prior to isolating total RNA containing miRs. The expression of miR-24 was amplified by reverse transcription polymerase chain reaction. Data are mean \pm S.E.M. from duplicate experiments $(n=3)$. U6 was used as the loading control and to normalize the expression of miR-24 in the samples. $* P<0.05$ vs. control. 


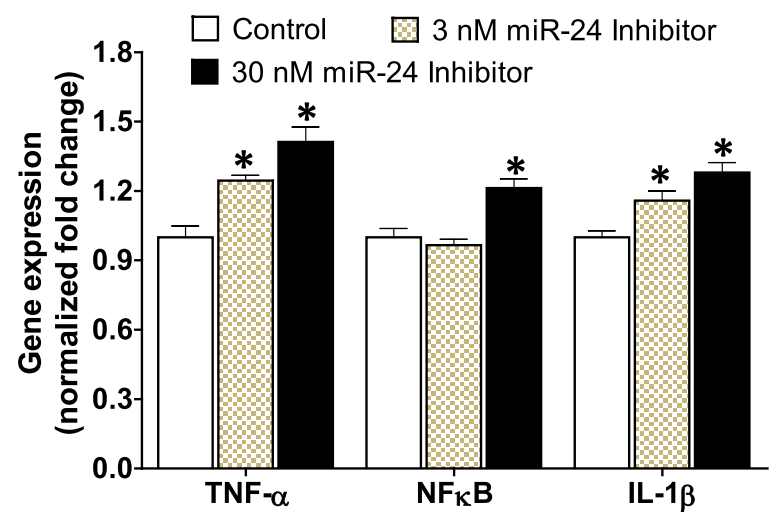

Fig. 4. Inhibition of miR-24 in human lung epithelial cells upregulates the expression of inflammatory cytokines: TNF- $\alpha, \mathrm{NF}_{\kappa} \mathrm{B}$, and IL- $1 \beta$. Primary human lung epithelial cells were treated with miR-24 inhibitor (3-30 nM) or control for 24 hours prior to isolating total RNA. The expression of proinflammatory genes was amplified by reverse transcription polymerase chain reaction. The housekeeping gene $\beta$-actin was used as the internal control and data were normalized to the control group. Data are mean \pm S.E.M. from duplicate experiments $(n=4)$. ${ }^{*} P<0.05$ vs. control.

proinflammatory molecules that are upregulated upon inhibition of miR-24 (Fig. 5), albeit to a greater extent, indicating that nicotine may induce inflammatory response in lung cells at least in part through inhibition of miR-24 and subsequent removal of repression on miR-24 targets. In addition, the TaqMan OpenArray Human Inflammation Panel (Life Technologies, Waltham, MA) screening revealed upregulation of inflammation-related genes following treatment of nicotine, including members of the tumor necrosis factor receptor superfamily (e.g., TNFRSF1B and TNFRSF4), IL2 receptor subunit B (IL2RB), IL17B, IL21 receptor, interferon $\alpha 5$, KLK1 kallikrein 1, bone morphogenetic proteins, serine protease inhibitor $\mathrm{A} 3$, integrin $\beta$, epoxide hydrolase 2 , and transcription factor TWIST1 (Supplemental Fig. 2). In addition, at higher nicotine concentration, there was a 48 -fold increase in the expression of the nAChR subunit $\alpha 7 \quad(\alpha 7$ nAChR; CHRNA7); a major subunit through which nicotine signals (Heeschen et al., 2001; Cooke and Ghebremariam, 2008).

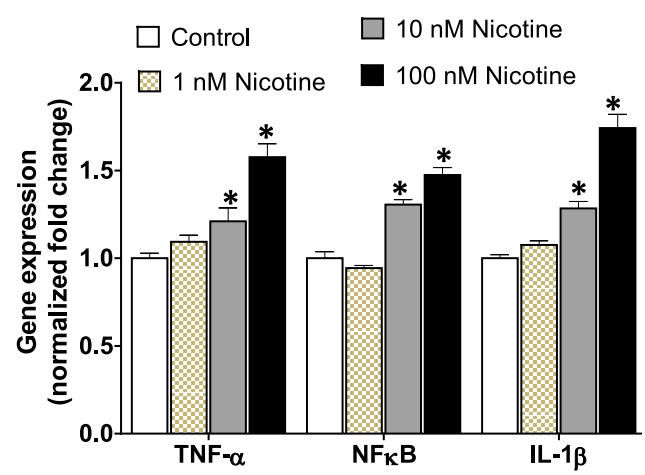

Fig. 5. Nicotine induces the expression of proinflammatory cytokines in lung epithelial cells. Human lung epithelial cells were treated with nicotine (1-100 $\mathrm{nM}$ ) or control for 24 hours. Total RNA was isolated and the expression of TNF- $\alpha, \mathrm{NF}_{\kappa} \mathrm{B}$, and IL- $1 \beta$ was profiled. $\beta$-actin was used as the internal control and data were normalized to the control group. Data are mean \pm S.E.M. from duplicate experiments. $* P<0.05$ vs. control $(n=4)$.
Nicotine and miR-24 Regulate Lung Cell Proliferation. Our proliferation study of human lung fibroblasts showed that nicotine dose dependently increased cell proliferation (Fig. 6A); miR-24 inhibition also enhanced the proliferation of human lung fibroblasts (Fig. 6B). Notably, FGF is a predicted miR-24 target that is also regulated by nicotine (Fig. 12). Basic FGF is essentially involved in the stimulation of fibroblasts and maintenance of their growth (Makino et al., 2010; Xiao et al., 2012). Overproliferation of fibroblasts is believed to contribute to abnormal deposition of an extracellular matrix in the lungs (Kendall and Feghali-Bostwick, 2014).

Nicotine Increased Soluble Collagen Release by Lung Fibroblasts. Measurement of collagen in TGF $\beta 1$-treated lung fibroblasts showed that cotreatment with nicotine significantly increased the amount of soluble collagen being released into the conditioned media (Fig. 7). However, selective miR-24 inhibition did not reproduce this effect. Several studies have reported that nicotine increases TGF $\beta 1$ expression and accelerates collagen accumulation in various cell types and organ systems (Sekhon et al., 2002; Goette et al., 2007; Rehan et al., 2007; Shan et al., 2009; Takeuchi et al., 2010; Soeda et al., 2012; Vicary et al., 2017). In addition, analysis of hits from our TaqMan OpenArray Human Inflammation Panel (Life Technologies) indicates that nicotine treatment of human lung fibroblasts modulated the expression of several genes, including those related to innate immunity (e.g., $\mathrm{NF}_{\kappa} \mathrm{B}, \mathrm{MEFV}$, and toll-like receptors), ligand-gated ion channels (e.g., ryanodine receptor 1 and purinergic receptor 7), oxidative stress (e.g., NADPH oxidase 4), and extracellular matrix turnover (e.g., bone morphogenetic protein 6) (Supplemental Fig. 3).

Nicotine Enhances the Release of Growth Factors from Lung Cells. ELISA-based measurement of growth factors (PDGF, FGF, and VEGF) in lung endothelial cells, a cell type known to be a major source of growth factors in physiologic and pathologic conditions (Bauters et al., 1999), showed enhanced secretion of these growth factors into conditioned media following nicotine stimulation (Fig. 8). Several studies in different cell types have reported the angiogenic property of nicotine, including excessive stimulation of growth factors (Cucina et al., 2000; Heeschen et al., 2001; Conklin et al., 2002; Grozio et al., 2007; Jensen et al., 2012). Similarly, inhibition of miR-24 with an antagomir mimicked the effect of nicotine, resulting in increased levels of all three growth factors (Fig. 9). Overstimulation of the mitogenic growth factors PDGF, FGF, and VEGF is implicated in the pathogenesis of lung fibrosis, and modulation of how these growth factors interact with their tyrosine kinase receptors is the basis for the pharmacological action of nintedanib; one of only two Food and Drug Administration-approved drugs for the treatment of IPF (Richeldi et al., 2014).

Prolonged Nicotine Exposure Upregulates the Expression of Myofibroblast Markers. Our immunofluorescence data demonstrate that prolonged exposure of lung fibroblasts to clinically relevant concentrations of nicotine increases the expression of the myofibroblast markers $\alpha$-SMA and type I collagen (Fig. 10), suggesting that nicotine directly contributes to the expansion of collagenproducing cells that form the basis of fibrotic lesions and matrix stiffness.

The Expression of Growth Factors Is Increased in IPF. Lung epithelial single cell RNA sequencing analysis from the lung gene expression analysis web portal (Du et al., 

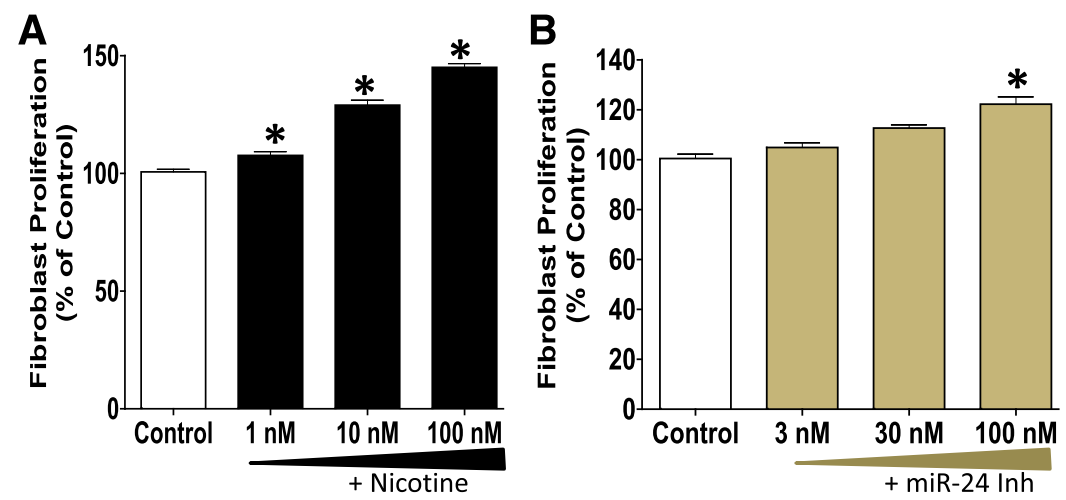

Fig. 6. The proliferation of lung fibroblasts is increased upon treatment with: (A) nicotine (1-100 nM) or (B) miR-24 inhibitor (3-100 $\mathrm{nM})$. Synchronized primary human lung fibroblasts (seeding density $=3 \times 10^{3}$ ) were treated with nicotine, miR-24 inhibitor, or control for 24 hours and allowed to proliferate in the presence of BrdU for an additional 22 hours. Cell proliferation was assessed using BrdU assay. Data are mean \pm S.E.M. from duplicate experiments $(n=3)$ and are expressed as the percentage of proliferation in the control groups. ${ }^{*} P<0.05$ vs. control; miR-24 Inh denotes miR-24 inhibitor.

2015, 2017) comparing single cells isolated from IPF patients and control lungs validated that expression of the three growth factors (PDGF, FGF, and VEGF) is increased in IPF compared with controls (Fig. 11).

\section{Discussion}

Several studies have demonstrated the expression of functional $\mathrm{nAChRs}$ in lung cells (Kummer et al., 2008; Maouche et al., 2009; Kummer and Krasteva-Christ, 2014). For example, Maouche et al. (2013) reported that $\alpha 7 \mathrm{nAChR}$ plays a major role in nicotine-mediated airway epithelium dysfunction. Additional studies (Sekhon et al., 1999, 2001; Wongtrakool et al., 2007; Maouche et al., 2009) have reported that the $\alpha 7 \mathrm{nAChR}$ controls lung development and morphogenesis, including airway epithelial cell proliferation and

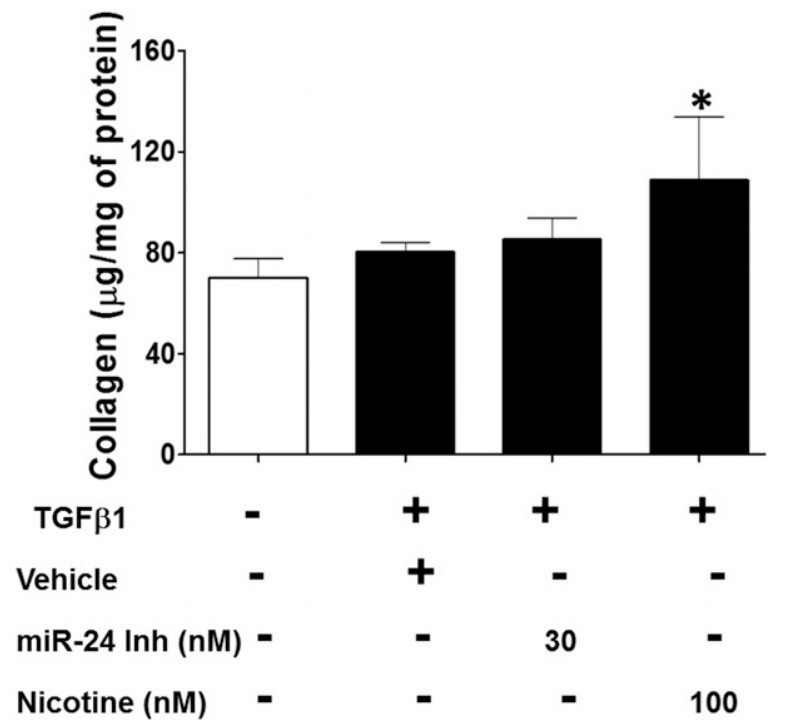

Fig. 7. Nicotine enhances soluble collagen release by lung fibroblasts. Primary human lung fibroblasts were seeded at $6 \times 10^{4}$ cells/well in sixwell plates. Synchronized cells were treated with recombinant human TGF $\beta 1(10 \mathrm{ng} / \mathrm{ml})$ in the presence of nicotine $(100 \mathrm{nM})$, miR-24 inhibitor (30 nM), or vehicle for 24 hours. Acid-soluble collagen content in each well was determined in the conditioned media using Sircol collagen assay. The amount of collagen in each well was estimated from a standard curve and the collagen content in each sample was normalized to total cellular protein. Data are expressed as microgram collagen per milligram of protein. Data are mean \pm S.E.M. from duplicate experiments $(n=3)$. $* P<$ 0.05 compared with no TGF $\beta$ control. differentiation, suggesting a key role of this $\mathrm{nAChR}$ subunit in airway remodeling and plasticity (Fig. 1).

Given the significance of the nAChRs in lung pathobiology, and the difficulty of characterizing all of the 5000 components of cigarette smoke, our current study was focused on the mechanisms by which a chief ingredient of tobacco smoke (i.e., nicotine) is associated with proinflammatory and profibrotic phenotypes in lung cells. Our preclinical study in an animal model of bleomycin-induced lung fibrosis revealed that miR24 , a microRNA recently reported to be significantly dysregulated in a major tobacco smoke-related vascular disease (Maegdefessel et al., 2014), was significantly downregulated upon lung injury (Fig. 2). This in vivo inhibition of miR-24 was reproduced in vitro upon treatment of lung epithelial cells with clinically relevant concentrations of nicotine (Fig. 3). In addition, our findings demonstrate that clinically relevant doses of nicotine upregulate proinflammatory, profibrotic, and proangiogenic molecules (Figs. 5-8 and 10). The inflammatory molecules that we found to be upregulated by nicotine include $\mathrm{TNF} \alpha, \mathrm{IL} 1 \beta$, and $\mathrm{NF}_{\kappa} \mathrm{B}$. The induced expression of these inflammatory molecules by nicotine was also mirrored by genetic ablation of miR-24 (Fig. 4), suggesting that nicotine controls these molecules at least in part through the inhibition

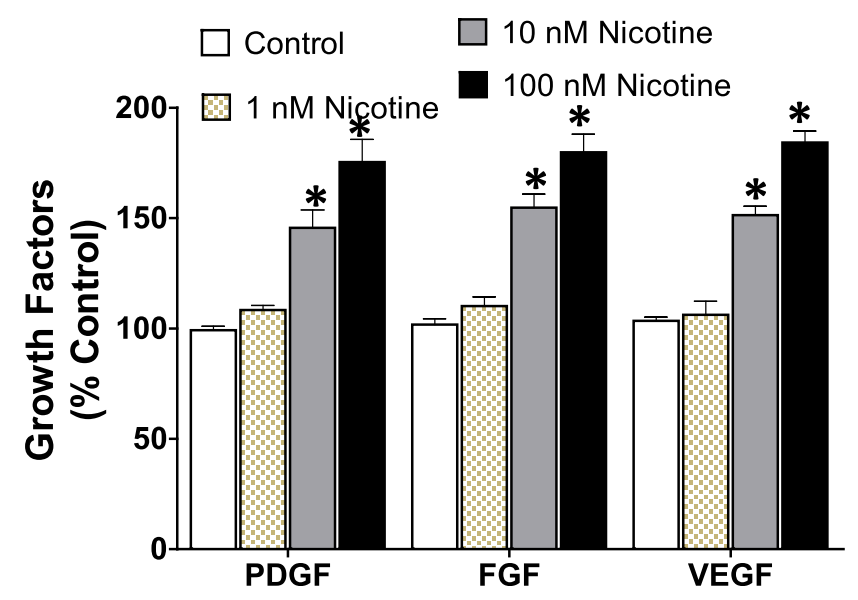

Fig. 8. Nicotine increases the expression of growth factors PDGF, FGF, and VEGF in lung endothelial cells. Primary human lung endothelial cells were seeded on $75 \mathrm{~cm}^{2}$ flasks until $80 \%$ confluency, and then treated with nicotine (1-100 nM) or control (PBS) for 24 hours. The concentration of the growth factors in the conditioned media was measured by ELISA (optical density: $450 \mathrm{~nm}$ readout) and calculated from the standard curve. Data were normalized to total cellular protein and are expressed as mean \pm S.E.M. from duplicate experiments $(n=3)$. ${ }^{*} P<0.05$ vs. control. 


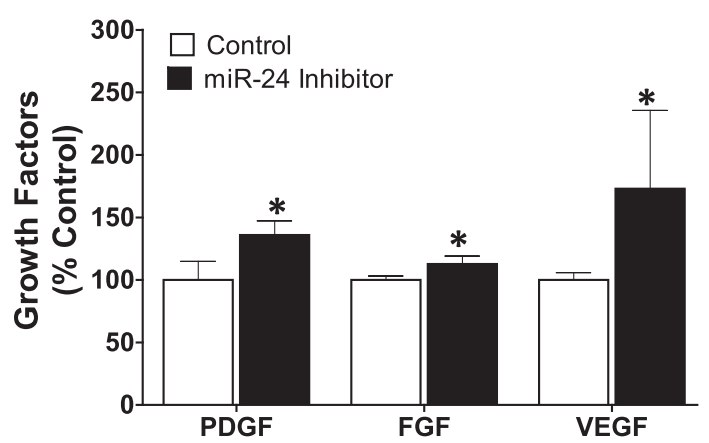

Fig. 9. Inhibition of miR-24 increases the expression of growth factors PDGF, FGF, and VEGF in lung endothelial cells. Primary human lung endothelial cells were seeded on $75 \mathrm{~cm}^{2}$ flasks until $80 \%$ confluency, and then treated with miR-24 inhibitor $(100 \mathrm{nM})$ or control miR for 24 hours. The intracellular growth factor concentration was measured by ELISA (optical density: $450 \mathrm{~nm}$ readout) and calculated from the standard curve. Data were normalized to total cellular protein and are expressed as mean \pm S.E.M. from duplicate experiments $(n=3) .{ }^{*} P<0.05$ vs. control.

of miR-24. In addition to the proinflammatory role, we found that nicotine was able to increase the amount of collagen secreted by lung fibroblasts in a miR-24-independent manner (Fig. 7), suggesting that nicotine does not directly depend on this miR to enhance collagen release. Our data also show that nicotine directly increased the proliferation of human lung fibroblasts (Fig. 6A) and their transition into myofibroblastlike cells (Fig. 10), suggesting the expansion of collagenproducing cells upon prolonged exposure to nicotine. This accelerated proliferation of lung fibroblasts by nicotine needs to be evaluated in other lung cell types, such as epithelial and endothelial cells, since a change in their proliferation kinetics may influence the course of inflammation and fibrosis in IPF (Willis et al., 2005; Selman and Pardo, 2006; Akram et al., 2014; Piera-Velazquez et al., 2016). Finally, the proangiogenic molecules PDGF, FGF, and VEGF were significantly induced by exposure of lung endothelial cells to nicotine (Fig. 8) or upon inhibition of miR-24 by an antagomir; albeit to a lesser extent (Fig. 9). These findings suggest that nicotine is partially dependent on miR-24 to regulate levels of these growth factors in lung endothelial cells. The inhibition of growth factors by nicotine is consistent with the mitogenic property of nicotine reported in the literature (Cucina et al., 2000; Heeschen et al., 2001; Conklin et al., 2002; Grozio et al., 2007; Jensen et al., 2012). Similarly, our analysis of the lung gene expression analysis web portal confirmed that the expression of PDGF, FGF, and VEGF is upregulated in lung epithelial cells derived from IPF patients compared with controls (Fig. 11). In general, the induction of these growth factors is believed to be positively associated with the disease process in IPF (Antoniades et al., 1990; MacKenzie et al., 2015; Atamas, 2017). For example, PDGF is known to act as a chemoattractant for lung fibroblasts and stimulate the accumulation of abnormal levels of collagen (Antoniades et al., 1990). Nintedanib, a drug that works by inhibiting the receptors for PDGF, FGF, and VEGF, has been shown to slow the rate of decline in lung function in patients with IPF (Richeldi et al., 2014).

Overall, our study provides some important insights into the mechanism(s) by which nicotine contributes to the development and/or progression of lung fibrosis. Our data suggest that nicotine may accelerate the disease process in IPF through excessive stimulation of growth factors and downregulation of anti-inflammatory miRs. The existing literature indicates that nicotine, through its receptors, is able to stimulate growth factors (Ng et al., 2007), induce oxidative stress (Barr et al., 2007), and promote inflammation (Hosseinzadeh et al., 2016). The stimulated proinflammatory molecules (Bringardner et al., 2008), mitogenic growth factors (Allen and Spiteri, 2002), and pro-oxidants (Cheresh et al., 2013) are known to promote lung inflammation and fibrogenesis (Fig. 12). Added to the existing literature is our study linking the effect of nicotine on anti-inflammatory microRNA. To date, the role of only a handful of microRNAs has been demonstrated in the IPF disease process. However, the effect of tobacco smoke or nicotine on lung miRs has not been fully explored. This differential effect of nicotine on growth factors and miRs has important implications in a number of respiratory diseases that extend beyond IPF. In the context of IPF, our study sheds some light on possible links between tobacco use, increased risk of lung disease, and subsequent

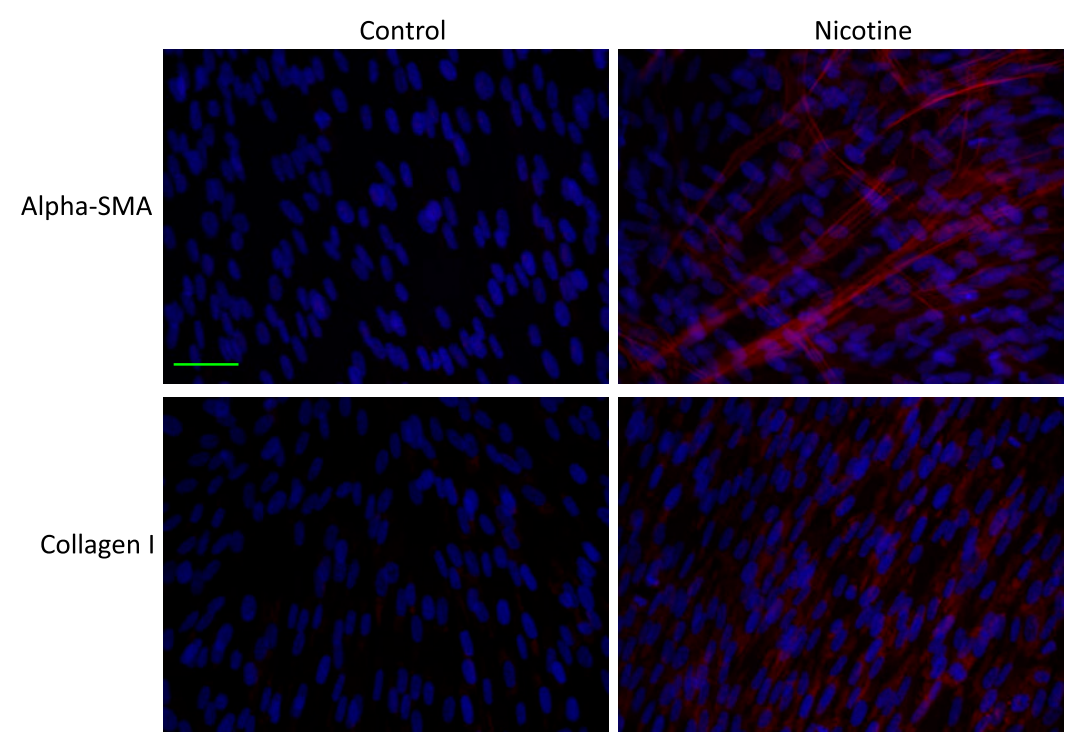

Fig. 10. Immunofluorescence stain showing increased expression of the myofibroblast markers $\alpha$-SMA and collagen I upon chronic exposure of lung fibroblasts to nicotine. Primary human lung fibroblasts were seeded in six-well plates and treated with nicotine $(100 \mathrm{nM})$ daily for 5 days. The cells were fixed, permeabilized, and stained for the myofibroblast markers: $\alpha$-SMA (1:400; Abcam), and collagen I (1:500; Abcam) $(n=3)$. Goat anti-rabbit (1:500; ThermoFisher) Alexa Fluor 594 secondary antibodies were used and are shown as red stain. The nuclei were stained with 4',6-diamidino-2-phenylindole and are shown as blue stain. Objective original magnification, $40 \times$; Scale bar, $50 \mu \mathrm{m}$ (applies to all the images in this figure). 
VEGFA: Expression in IPF and Control

10

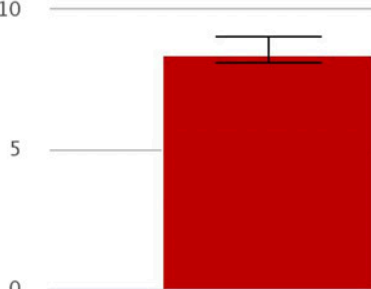

IPF

PDGFA: Expression in IPF and Control

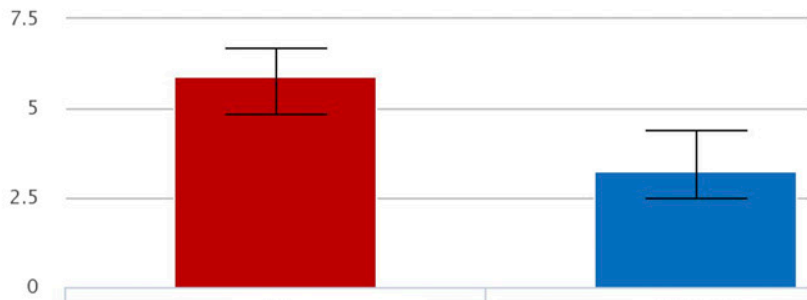

IPF

PDGFC: Expression in IPF and Control

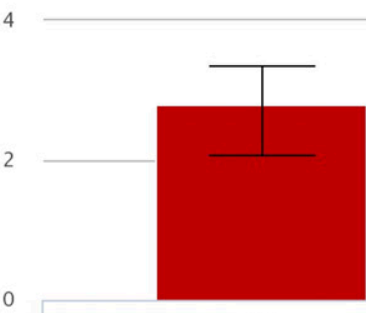

IPF

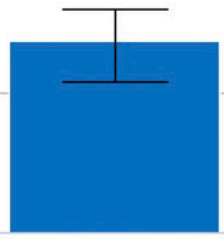

CONTROL

VEGFC: Expression in IPF and Control

1.5

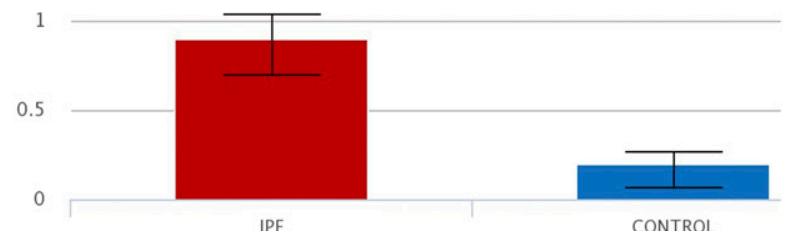

PDGFB: Expression in IPF and Control

0.3

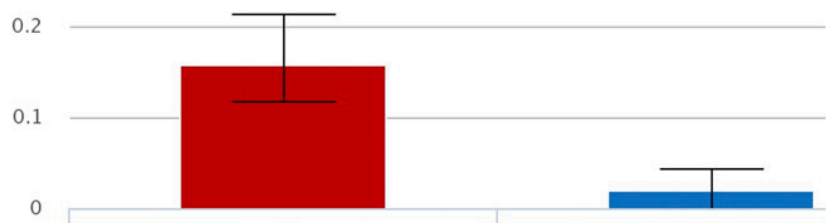

IPF

CONTROL

FGF2: Expression in IPF and Control

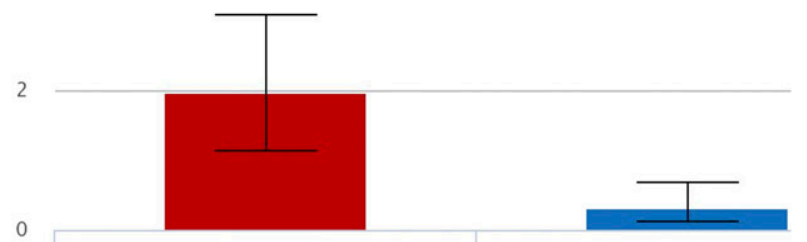

IPF

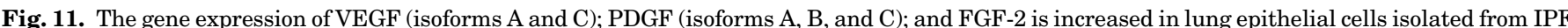

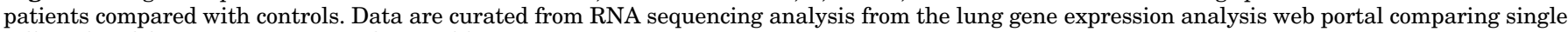
cells isolated from IPF patients and control lungs.

accelerated loss of lung function (Oh et al., 2012). The conflicting data on the effect of tobacco smoke (e.g., the "healthy smoker effect") on the incidence and severity of some chronic lung diseases and overall survival of patients (Valeyre et al., 1988; Peros-Golubicić and Ljubić, 1995; Vassallo and Ryu, 2012; Margaritopoulos et al., 2015) may be reconciled by understanding the differential contribution of major tobacco smoke components on the pathophysiology of lung cells, including cell survival and function.
In conclusion, we have linked the simultaneous effect of nicotine on growth factors and microRNA in lung cells. Further mechanistic understanding of the pathologic effect of nicotine in cigarette smoke is likely to unlock additional research opportunities to study possible adverse effects of the nicotine present in e-cigarettes, chewing tobacco, and nicotine replacement therapy (a current interventional strategy developed for the cessation of mainstream tobacco smoke).

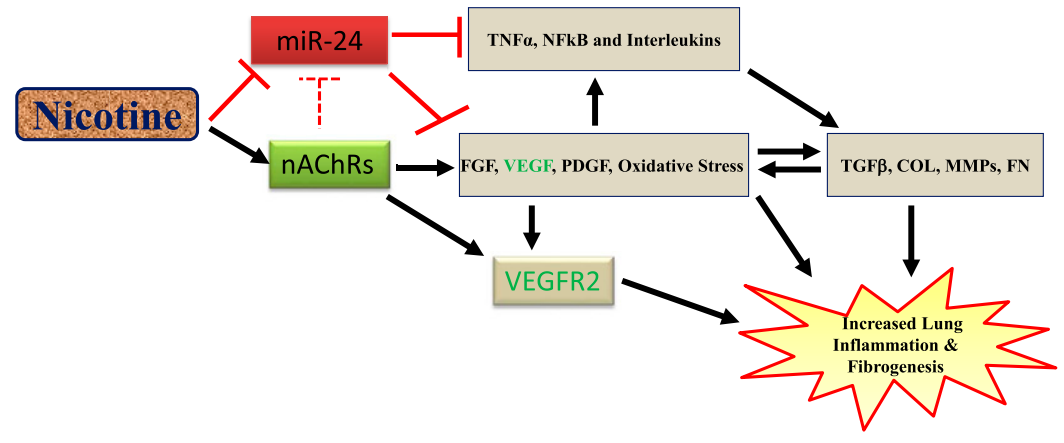

Fig. 12. Schematic showing the potential mechanism of accelerated lung inflammation and fibrosis by nicotine. As shown, nicotine internalizes through the endogenous nAChRs to promote growth factors (VEGF, FGF, and PDGF) and induce oxidative stress, which in turn stimulates profibrotic molecules (TGF $\beta$, collagen, fibronectin, and metalloproteinases). In addition, we propose that nicotine suppresses anti-inflammatory microRNA such as miR-24 to derepress the expression of inflammatory cytokines including $\mathrm{TNF} \alpha, \mathrm{NF}_{\kappa} \mathrm{B}$, and interleukins, which are known to interact with mitogenic growth factors and profibrotic molecules to promote aberrant lung remodeling. 


\section{Authorship Contributions}

Participated in research design: Ebrahimpour, Shrestha, Ghebre. Conducted experiments: Ebrahimpour, Shrestha, Ghebre.

Contributed new reagents or analytic tools: Ebrahimpour, Ghebre. Performed data analysis: Ebrahimpour, Ghebre.

Wrote or contributed to the writing of the manuscript: Ebrahimpour, Bonnen, Eissa, Raghu, Ghebre.

\section{References}

Akram KM, Lomas NJ, Forsyth NR, and Spiteri MA (2014) Alveolar epithelial cells in idiopathic pulmonary fibrosis display upregulation of TRAIL, DR4 and DR5 expression with simultaneous preferential over-expression of pro-apoptotic marker p53. Int J Clin Exp Pathol 7:552-564.

Allen JT and Spiteri MA (2002) Growth factors in idiopathic pulmonary fibrosis: relative roles. Respir Res $3: 13$.

Antoniades HN, Bravo MA, Avila RE, Galanopoulos T, Neville-Golden J, Maxwell M, and Selman M (1990) Platelet-derived growth factor in idiopathic pulmonary fibrosis. J Clin Invest 86:1055-1064.

Atamas SP (2017) Vascular endothelial growth factor in idiopathic pulmonary fibrosis. An imbalancing act. Am J Respir Crit Care Med 196:409-411.

Barr J, Sharma CS, Sarkar S, Wise K, Dong L, Periyakaruppan A, and Ramesh GT (2007) Nicotine induces oxidative stress and activates nuclear transcription factor kappa B in rat mesencephalic cells. Mol Cell Biochem 297:93-99.

Bauters C, Six I, Meurice T, and Van Belle E (1999) Growth factors and endothelial dysfunction. Drugs 59:11-15.

Bellaye PS and Kolb M (2015) Why do patients get idiopathic pulmonary fibrosis? Current concepts in the pathogenesis of pulmonary fibrosis. BMC Med 13: 176.

Bringardner BD, Baran CP, Eubank TD, and Marsh CB (2008) The role of inflammation in the pathogenesis of idiopathic pulmonary fibrosis. Antioxid Redox Signal 10:287-301.

Carlisle DL, Hopkins TM, Gaither-Davis A, Silhanek MJ, Luketich JD, Christie NA and Siegfried JM (2004) Nicotine signals through muscle-type and neuronal nicotinic acetylcholine receptors in both human bronchial epithelial cells and airway fibroblasts. Respir Res 5:27.

Carty CS, Soloway PD, Kayastha S, Bauer J, Marsan B, Ricotta JJ, and Dryjski M (1996) Nicotine and cotinine stimulate secretion of basic fibroblast growth factor and affect expression of matrix metalloproteinases in cultured human smooth muscle cells [published correction appears in J Vasc Surg (1997) 25:628]. J Vasc Surg 24:927-934; discussion 934-925.

Cheresh P, Kim SJ, Tulasiram S, and Kamp DW (2013) Oxidative stress and pulmonary fibrosis. Biochim Biophys Acta 1832:1028-1040.

Conklin BS, Zhao W, Zhong DS, and Chen C (2002) Nicotine and cotinine up-regulate vascular endothelial growth factor expression in endothelial cells. Am J Pathol 160:413-418.

Cooke JP and Ghebremariam YT (2008) Endothelial nicotinic acetylcholine receptors and angiogenesis. Trends Cardiovasc Med 18:247-253.

Cucina A, Sapienza P, Corvino V, Borrelli V, Mariani V, Randone B, Santoro D'Angelo L, and Cavallaro A (2000) Nicotine-induced smooth muscle cell proliferation is mediated through bFGF and TGF- $\beta 1$. Surgery 127:316-322.

dos Santos G, Kutuzov MA, and Ridge KM (2012) The inflammasome in lung diseases. Am J Physiol Lung Cell Mol Physiol 303:L627-L633.

Du Y, Guo M, Whitsett JA, and Xu Y (2015) 'LungGENS': a web-based tool for mapping single-cell gene expression in the developing lung. Thorax 70:1092-1094.

Du Y, Kitzmiller JA, Sridharan A, Perl AK, Bridges JP, Misra RS, Pryhuber GS, Mariani TJ, Bhattacharya S, Guo M, et al. (2017) Lung gene expression analysis (LGEA): an integrative web portal for comprehensive gene expression data analysis in lung development. Thorax 72:481-484.

Duan JJ, Lozada AF, Gou CY, Xu J, Chen Y, and Berg DK (2015) Nicotine recruits glutamate receptors to postsynaptic sites. Mol Cell Neurosci 68:340-349.

Ghebremariam YT, Cooke JP, Gerhart W, Griego C, Brower JB, Doyle-Eisele M, Moeller BC, Zhou Q, Ho L, de Andrade J, et al. (2015) Pleiotropic effect of the proton pump inhibitor esomeprazole leading to suppression of lung inflammation and fibrosis. J Transl Med 13:249.

Goette A, Lendeckel U, Kuchenbecker A, Bukowska A, Peters B, Klein HU, Huth C, and Röcken C (2007) Cigarette smoking induces atrial fibrosis in humans via nicotine. Heart 93:1056-1063.

Grozio A, Catassi A, Cavalieri Z, Paleari L, Cesario A, and Russo P (2007) Nicotine, lung and cancer. Anticancer Agents Med Chem 7:461-466.

Hagood JS (2014) Beyond the genome: epigenetic mechanisms in lung remodeling. Physiology (Bethesda) 29:177-185.

Heeschen C, Jang JJ, Weis M, Pathak A, Kaji S, Hu RS, Tsao PS, Johnson FL, and Cooke JP (2001) Nicotine stimulates angiogenesis and promotes tumor growth and atherosclerosis. Nat Med 7:833-839.

Heijink IH, Brandenburg SM, Postma DS, and van Oosterhout AJ (2012) Cigarette smoke impairs airway epithelial barrier function and cell-cell contact recovery. Eur Respir J 39:419-428.

Hill P, Haley NJ, and Wynder EL (1983) Cigarette smoking: carboxyhemoglobin, plasma nicotine, cotinine and thiocyanate vs self-reported smoking data and cardiovascular disease. J Chronic Dis 36:439-449.

Hosseinzadeh A, Thompson PR, Segal BH, and Urban CF (2016) Nicotine induces neutrophil extracellular traps. J Leukoc Biol 100:1105-1112.

Jensen K, Nizamutdinov D, Guerrier M, Afroze S, Dostal D, and Glaser S (2012) General mechanisms of nicotine-induced fibrogenesis. FASEB $J \mathbf{2 6}$ 4778-4787.

Kendall RT and Feghali-Bostwick CA (2014) Fibroblasts in fibrosis: novel roles and mediators. Front Pharmacol 5:123.
Kolb M, Margetts PJ, Anthony DC, Pitossi F, and Gauldie J (2001) Transient expression of IL- $1 \beta$ induces acute lung injury and chronic repair leading to pulmonary fibrosis. $J$ Clin Invest 107:1529-1536.

Kuipers I, Guala AS, Aesif SW, Konings G, Bouwman FG, Mariman EC, Wouters EF, Janssen-Heininger YM, and Reynaert NL (2011) Cigarette smoke targets glutaredoxin 1, increasing S-glutathionylation and epithelial cell death. Am J Respir Cell Mol Biol 45:931-937.

Kummer W and Krasteva-Christ G (2014) Non-neuronal cholinergic airway epithelium biology. Curr Opin Pharmacol 16:43-49.

Kummer W, Lips KS, and Pfeil U (2008) The epithelial cholinergic system of the airways. Histochem Cell Biol 130:219-234.

Lam DC, Luo SY, Fu KH, Lui MM, Chan KH, Wistuba II, Gao B, Tsao SW, Ip MS, and Minna JD (2016) Nicotinic acetylcholine receptor expression in human airway correlates with lung function. Am J Physiol Lung Cell Mol Physiol 310:L232-L239.

Lee RC, Feinbaum RL, and Ambros V (1993) The C. elegans heterochronic gene lin-4 encodes small RNAs with antisense complementarity to lin-14. Cell 75:843-854.

Lino Cardenas CL, Kaminski N, and Kass DJ (2013) Micromanaging microRNAs: using murine models to study microRNAs in lung fibrosis. Drug Discov Today Dis Models 10:e145-e151.

MacKenzie B, Korfei M, Henneke I, Sibinska Z, Tian X, Hezel S, Dilai S, Wasnick R, Schneider B, Wilhelm J, et al. (2015) Increased FGF1-FGFRc expression in idiopathic pulmonary fibrosis. Respir Res 16:83.

Maegdefessel L, Spin JM, Raaz U, Eken SM, Toh R, Azuma J, Adam M, Nakagami F, Heymann HM, Chernogubova E, et al. (2014) miR-24 limits aortic vascular inflammation and murine abdominal aneurysm development [published correction appears in Nat Commun (2015) 6:6506]. Nat Commun 5:5214

Makino T, Jinnin M, Muchemwa FC, Fukushima S, Kogushi-Nishi H, Moriya C, Igata T, Fujisawa A, Johno T, and Ihn H (2010) Basic fibroblast growth factor stimulates the proliferation of human dermal fibroblasts via the ERK1/2 and JNK pathways. Br J Dermatol 162:717-723.

Maouche K, Medjber K, Zahm JM, Delavoie F, Terryn C, Coraux C, Pons S, CloëzTayarani I, Maskos U, Birembaut P, et al. (2013) Contribution of $\alpha 7$ nicotinic receptor to airway epithelium dysfunction under nicotine exposure. Proc Natl Acad Sci USA 110:4099-4104.

Maouche K, Polette M, Jolly T, Medjber K, Cloëz-Tayarani I, Changeux JP, Burlet H, Terryn C, Coraux C, Zahm JM, et al. (2009) $\alpha 7$ Nicotinic acetylcholine receptor regulates airway epithelium differentiation by controlling basal cell proliferation. Am J Pathol 175:1868-1882.

Margaritopoulos GA, Harari S, Caminati A, and Antoniou KM (2016) Smokingrelated idiopathic interstitial pneumonia: a review. Respirology 21:57-64.

Margaritopoulos GA, Vasarmidi E, Jacob J, Wells AU, and Antoniou KM (2015) Smoking and interstitial lung diseases. Eur Respir Rev 24:428-435.

Matta SG, Balfour DJ, Benowitz NL, Boyd RT, Buccafusco JJ, Caggiula AR, Craig CR, Collins AC, Damaj MI, Donny EC, et al. (2007) Guidelines on nicotine dose selection for in vivo research. Psychopharmacology (Berl) 190:269-319.

Maus $\mathrm{AD}$, Pereira EF, Karachunski PI, Horton RM, Navaneetham D, Macklin K, Cortes WS, Albuquerque EX, and Conti-Fine BM (1998) Human and rodent bronchial epithelial cells express functional nicotinic acetylcholine receptors. Mo Pharmacol 54:779-788.

Milosevic J, Pandit K, Magister M, Rabinovich E, Ellwanger DC, Yu G, Vuga LJ, Weksler B, Benos PV, Gibson KF, et al. (2012) Profibrotic role of miR-154 in pulmonary fibrosis. Am J Respir Cell Mol Biol 47:879-887.

Montgomery RL, Yu G, Latimer PA, Stack C, Robinson K, Dalby CM, Kaminski N, and van Rooij E (2014) MicroRNA mimicry blocks pulmonary fibrosis. EMBO Mol Med 6:1347-1356.

Nastrucci C and Russo P (2012) $\alpha 7 \mathrm{nAChR}$ in airway respiratory epithelial cells. Curr Drug Targets 13:666-670.

Ng MK, Wu J, Chang E, Wang BY, Katzenberg-Clark R, Ishii-Watabe A, and Cooke JP (2007) A central role for nicotinic cholinergic regulation of growth factorinduced endothelial cell migration. Arterioscler Thromb Vasc Biol 27:106-112.

Nouri-Shirazi M, Kahlden C, Nishino P, and Guinet E (2015) Nicotine exposure alters the mRNA expression of notch ligands in dendritic cells and their response to Th1-/Th2-promoting stimuli. Scand J Immunol 81:110-120.

Nyunoya T, Mebratu Y, Contreras A, Delgado M, Chand HS, and Tesfaigzi Y (2014) Molecular processes that drive cigarette smoke-induced epithelial cell fate of the lung. Am J Respir Cell Mol Biol 50:471-482.

Oh CK, Murray LA, and Molfino NA (2012) Smoking and idiopathic pulmonary fibrosis. Pulm Med 2012:808260.

Oikonomou N, Harokopos V, Zalevsky J, Valavanis C, Kotanidou A, Szymkowski DE Kollias G, and Aidinis V (2006) Soluble TNF mediates the transition from pulmonary inflammation to fibrosis. PLoS One 1:e108.

Ornitz DM and Itoh N (2015) The fibroblast growth factor signaling pathway. Wiley Interdiscip Rev Dev Biol 4:215-266.

Pandit KV, Corcoran D, Yousef H, Yarlagadda M, Tzouvelekis A, Gibson KF, Konishi K, Yousem SA, Singh M, Handley D, et al. (2010) Inhibition and role of let-7d in idiopathic pulmonary fibrosis. Am J Respir Crit Care Med 182:220-229.

Pandit KV and Milosevic J (2015) MicroRNA regulatory networks in idiopathic pulmonary fibrosis. Biochem Cell Biol 93:129-137.

Pandit KV, Milosevic J, and Kaminski N (2011) MicroRNAs in idiopathic pulmonary fibrosis. Transl Res 157:191-199.

Peros-Golubicić T and Ljubić S (1995) Cigarette smoking and sarcoidosis. Acta Med Croatica 49:187-193.

Piera-Velazquez S, Mendoza FA, and Jimenez SA (2016) Endothelial to mesenchymal transition (EndoMT) in the pathogenesis of human fibrotic diseases. $J$ Clin Med 5:45.

Raghu G, Chen SY, Yeh WS, Maroni B, Li Q, Lee YC, and Collard HR (2014) Idiopathic pulmonary fibrosis in US medicare beneficiaries aged 65 years and older: incidence, prevalence, and survival, 2001-11. Lancet Respir Med 2:566-572.

Raghu G, Rochwerg B, Zhang Y, Garcia CA, Azuma A, Behr J, Brozek JL, Collard HR, Cunningham W, Homma S, et al.; American Thoracic Society; European 
Respiratory society; Japanese Respiratory Society; Latin American Thoracic Association (2015) An official ATS/ERS/JRS/ALAT clinical practice guideline: treatment of idiopathic pulmonary fibrosis. An update of the 2011 clinical practice guideline [published correction appears in Am J Respir Crit Care Med (2015) 192: 644]. Am J Respir Crit Care Med 192:e3-e19.

Raghu G and Thickett DR (2013) Pirfenidone for IPF: pro/con debate; the 'con' viewpoint. Thorax 68:605-608.

Rehan VK, Wang Y, Sugano S, Santos J, Patel S, Sakurai R, Boros LG, Lee WP and Torday JS (2007) In utero nicotine exposure alters fetal rat lung alveolar type II cell proliferation, differentiation, and metabolism [published correction appears in Am J Physiol Lung Cell Mol Physiol (2007) 293:L820. Am J Physiol Lung Cell Mol Physiol 292:L323-L333.

Richeldi L, du Bois RM, Raghu G, Azuma A, Brown KK, Costabel U, Cottin V, Flaherty KR, Hansell DM, Inoue Y, et al.; INPULSIS Trial Investigators (2014) Efficacy and safety of nintedanib in idiopathic pulmonary fibrosis. $N \mathrm{Engl} \mathrm{J} \mathrm{Med}$ 370:2071-2082.

Ryu JH, Colby TV, Hartman TE, and Vassallo R (2001) Smoking-related interstitial lung diseases: a concise review. Eur Respir J 17:122-132.

Samara KD, Margaritopoulos G, Wells AU, Siafakas NM, and Antoniou KM (2011) Smoking and pulmonary fibrosis: novel insights. Pulm Med 2011:461439.

Schweitzer KS, Chen SX, Law S, Van Demark M, Poirier C, Justice MJ, Hubbard WC, Kim ES, Lai X, Wang M, et al. (2015) Endothelial disruptive proinflammatory effects of nicotine and e-cigarette vapor exposures. Am J Physiol Lung Cell Mol Physiol 309:L175-L187.

Sekhon HS, Jia Y, Raab R, Kuryatov A, Pankow JF, Whitsett JA, Lindstrom J, and Spindel ER (1999) Prenatal nicotine increases pulmonary $\alpha 7$ nicotinic receptor expression and alters fetal lung development in monkeys. $J$ Clin Invest 103 637-647.

Sekhon HS, Keller JA, Benowitz NL, and Spindel ER (2001) Prenatal nicotine exposure alters pulmonary function in newborn rhesus monkeys. Am J Respir Crit Care Med 164:989-994.

Sekhon HS, Keller JA, Proskocil BJ, Martin EL, and Spindel ER (2002) Materna nicotine exposure upregulates collagen gene expression in fetal monkey lung. Association with $\alpha 7$ nicotinic acetylcholine receptors. Am J Respir Cell Mol Biol 26 $31-41$.

Selman M and Pardo A (2006) Role of epithelial cells in idiopathic pulmonary fibrosis from innocent targets to serial killers. Proc Am Thorac Soc 3:364-372.

Serrano-Mollar A, Closa D, Prats N, Blesa S, Martinez-Losa M, Cortijo J, Estrela JM, Morcillo EJ, and Bulbena O (2003) In vivo antioxidant treatment protects against bleomycin-induced lung damage in rats. $B r J$ Pharmacol 138: 1037-1048.

Shan H, Zhang Y, Lu Y, Zhang Y, Pan Z, Cai B, Wang N, Li X, Feng T, Hong Y, et al (2009) Downregulation of miR-133 and miR-590 contributes to nicotine-induced atrial remodelling in canines. Cardiovasc Res 83:465-472.

Soeda J, Morgan M, McKee C, Mouralidarane A, Lin C, Roskams T, and Oben JA (2012) Nicotine induces fibrogenic changes in human liver via nicotinic acetylcholine receptors expressed on hepatic stellate cells. Biochem Biophys Res Commun 417:17-22.

Solleti SK, Simon DM, Srisuma S, Arikan MC, Bhattacharya S, Rangasamy T, Bijli KM, Rahman A, Crossno JT Jr., Shapiro SD, et al. (2015) Airway epithelial cell
PPAR $\gamma$ modulates cigarette smoke-induced chemokine expression and emphysema susceptibility in mice. Am J Physiol Lung Cell Mol Physiol 309:L293-L304.

Takeuchi H, Kubota S, Murakashi E, Zhou Y, Endo K, Ng PS, Takigawa M, and Numabe Y (2010) Nicotine-induced CCN2: from smoking to periodontal fibrosis. J Dent Res 89:34-39.

Taki FA, Pan X, and Zhang B (2014) Chronic nicotine exposure systemically alters microRNA expression profiles during post-embryonic stages in Caenorhabditis elegans. J Cell Physiol 229:79-89.

Talhout R, Schulz T, Florek E, van Benthem J, Wester P, and Opperhuizen A (2011) Hazardous compounds in tobacco smoke. Int J Environ Res Public Health 8:613-628

Valeyre D, Soler P, Clerici C, Pré J, Battesti JP, Georges R, and Hance A.J (1988) Smoking and pulmonary sarcoidosis: effect of cigarette smoking on prevalence, clinical manifestations, alveolitis, and evolution of the disease. Thorax 43:516-524.

Vassallo R and Ryu JH (2012) Smoking-related interstitial lung diseases. Clin Chest Med 33:165-178.

Vella MC and Slack FJ (2005) C. elegans microRNAs (September 21, 2005), WormBook, ed. The C. elegans Research Community, WormBook, doi: 10.1895/ wormbook.1.26.1, http://www.wormbook.org.

Vicary GW, Ritzenthaler JD, Panchabhai TS, Torres-González E, and Roman J (2017) Nicotine stimulates collagen type I expression in lung via $\alpha 7$ nicotinic acetylcholine receptors. Respir Res 18:115.

Willis BC, Liebler JM, Luby-Phelps K, Nicholson AG, Crandall ED, du Bois RM, and Borok Z (2005) Induction of epithelial-mesenchymal transition in alveolar epithelial cells by transforming growth factor- $\beta 1$ : potential role in idiopathic pulmonary fibrosis. Am J Pathol 166:1321-1332.

Wilson MS, Madala SK, Ramalingam TR, Gochuico BR, Rosas IO, Cheever AW, and Wynn TA (2010) Bleomycin and IL- $1 \beta$-mediated pulmonary fibrosis is IL-17A dependent. J Exp Med 207:535-552.

Wongtrakool C, Roser-Page S, Rivera HN, and Roman J (2007) Nicotine alters lung branching morphogenesis through the $\alpha 7$ nicotinic acetylcholine receptor. Am J Physiol Lung Cell Mol Physiol 293:L611-L618.

Xiao L, Du Y, Shen Y, He Y, Zhao H, and Li Z (2012) TGF-beta 1 induced fibroblast proliferation is mediated by the FGF-2/ERK pathway. Front Biosci 17:2667-2674.

Yang IV and Schwartz DA (2015) Epigenetics of idiopathic pulmonary fibrosis. Transl Res 165:48-60.

Yang S, Banerjee S, de Freitas A, Sanders YY, Ding Q, Matalon S, Thannickal VJ, Abraham E, and Liu G (2012) Participation of miR-200 in pulmonary fibrosis. Am $J$ Pathol 180:484-493.

Yang S, Cui H, Xie N, Icyuz M, Banerjee S, Antony VB, Abraham E, Thannickal VJ, and Liu G (2013) miR-145 regulates myofibroblast differentiation and lung fibrosis. FASEB J 27:2382-2391.

Zhou Y, Peng H, Sun H, Peng X, Tang C, Gan Y, Chen X, Mathur A, Hu B, Slade MD, et al. (2014) Chitinase 3-like 1 suppresses injury and promotes fibroproliferative responses in mammalian lung fibrosis. Sci Transl Med 6:240ra76.

Address correspondence to: Dr. Yohannes T. Ghebre, Department of Radiation Oncology, Baylor College of Medicine, One Baylor Plaza, Neurosensory Building NB335, Houston, TX 77030. E-mail: yohannes.ghebre@bcm.edu 